\title{
STUDI PENAMBAHAN SERAI (Cymbopogon citratus) DAN TEMU MANGGA (Curcuma mangga) TERHADAP KARAKTERISTIK FISIKOKIMIA DAN ORGANOLEPTIK MINUMAN SARI UMBI BIT (Beta vulagris L.)
}

Study of Addition Lemongrass (Cymbopogon citratus) and Turmeric Mango (Curcuma mango) on Physical-Chemistry and Organoleptic Characteristics of Beetroot Juice (Beta vulgaris L.)

\author{
Inten Sharon Datuyanan $^{1) *}$, Bistok Hasiholan Simanjuntak ${ }^{1)}$, Andree Wijaya Setiawan ${ }^{1)}$, \\ Yoga Aji Handoko ${ }^{1)}$ \\ ${ }^{1)}$ Jurusan Agroteknologi, Fakultas Pertanian dan Bisnis, Universitas Kristen Satya Wacana \\ Jalan Diponegoro 66 Salatiga, 50711 \\ *Korespondensi Penulis: intensharond@gmail.com
}

\begin{abstract}
As food contains vitamin, mineral and antioxidant, beetroot (Beta vulgaris L.) had beneficial for health. Although beetroot contains a lot of nutritional value, beetroot is less liked by the public because of an earthy taste. For this reason, it needs innovation of the beetroot processing into products that can be accepted by the public, such as beverage fruit drink with food additives. In this study, beetroot juice with food additives, i.e. lemongrass, and turmeric mango was expected to improve taste and acceptable consumer. This study were aimed to analyze the effect of lemongrass and turmeric mango on physicochemical characteristics and determine the organoleptic quality of beetroot juice. This study used a Randomized Block Design (RBD) with the addition of lemongrass and turmeric mango respectively 1\%, 3\%, 5\% concentration in the beetroot juice. Negative control used beetroot juice plain and the positive control used beet juice plus honey. Data were analyzed by variance (ANOVA), if the results obtained were significantly different, the DMRT continuing with 5\% significant level. The results showed that the addition of lemongrass and turmeric mango with the concentration of each 1\%, 3\%, $5 \%$ effect on the physicochemical characteristics and organoleptic beet juice. The highest total dissolved solids was $6.92^{\circ}$ Brix and the highest betacyanin content of $10.26 \mathrm{mg} / \mathrm{L}$ occurred at the addition of $5 \%$ turmeric mango. The highest $\mathrm{pH}$ value was shown in the negative control (beetroot juice plain) with an average of 6.52. The highest vitamin $C$ content found in the addition of $1 \%$ lemongrass about $6.16 \mathrm{mg} / 100 \mathrm{~g}$. The results also showed that the organoleptic beet juice with the addition of $1 \%$ lemongrass and the positive control (beet juice plus honey) as a sample that it the most preferred by the panelists.
\end{abstract}

Keywords: beetroot juice, lemongrass, physical-chemistry, organoleptic, turmeric mango

\section{PENDAHULUAN}

Indonesia adalah negara beriklim tropis, sehingga masyarakat cenderung mengkonsumsi banyak air sebagai penyegar tubuh. Seiring meningkatnya perkembangan teknologi dan keinginan masyarakat berpola hidup yang sehat, maka diperlukan minuman yang memiliki nilai fungsional. Salah satunya adalah minuman sari buah. Minuman sari buah merupakan minuman yang diperoleh dengan campuran air minum, tidak difermentasi, bagian lain dari satu jenis buah atau lebih, dengan atau tanpa penambahan gula, dan bahan tambahan pangan yang diizinkan (BSN, 1995) .

Umbi bit merupakan salah satu bahan pangan yang sangat bermanfaat bagi kesehatan tubuh, karena memiliki kandungan gizi yang cukup tinggi diantaranya mengandung vitamin seperti vitamin $\mathrm{A}$, asam askorbat (C), thiamin (B1), niacin (B3), riboflavin (B2), pentothenic acid (B5), vitamin B6 dan mineral seperti sodium, kalsium, iron, fosfor, kalium, magnesium, dan seng 
(Székely et al., 2019). Selain itu, bit juga memiliki kandungan antioksidan yang tinggi (Wootton-Beard et al., 2011) yang terkandung dalam pigmen betalain. (Mastuti, 2010) menyatakan bahwa pigmen betalain bersifat larut dalam air yang terbagi dalam dua sub-klas, yaitu betasianin berwarna merah keunguan dan betasantin berwarna kuning.

Meskipun umbi bit mengandung nilai gizi yang bagus dengan banyak manfaat, namun umbi bit memiliki kelemahan yaitu rasa umbi bit yang terasa aneh seperti rasa tanah atau earthy taste (Chasparinda et al., 2014) sehingga kurang diminati masyarakat. Hal ini dibuktikan dengan kurang dari $1 \%$ penduduk Indonesia yang mengonsumsi bit, sehingga umbi bit masih belum banyak dimanfaatkan oleh masyarakat Indonesia secara luas (Riskesdas, 2010). Oleh karena itu, untuk meminimalisir rasa dan aroma tanah yang kuat pada umbi bit, diperlukan bahan tambahan pangan, sehingga dapat mengurai rasa dan aroma umbi bit yang tidak disukai. Penambahan serai dan temu mangga yang memiliki aroma khas diharapkan dapat menjadi alternatif sebagai bahan tambahan dalam sari umbi bit, supaya dapat diterima oleh masyarakat. Namun pada sisi lain, nilai gizinya juga bertambah. Serai (Cymbopogon citratus) beraroma wangi khas karena memiliki kandungan minyak atsiri dengan komponen utama sitronelol dan geraniol (Agusta, 2002). Temu mangga (Curcuma mangga) memiliki aroma khas seperti mangga kweni dan rasanya tidak pahit. Kandungan senyawa kimia temu mangga adalah kurkuminoid, flavonoid, polifenol yang merupakan senyawa antioksidan yang mampu menekan radikal bebas (Ariviani dan Yani, 2013) serta minyak atsiri (Sarjono dan Mulyani, 2007). Berdasarkan manfaat dan komponen umbi bit serta peran serai dan temu mangga, maka penambahan bahan-bahan ini diharapkan akan meningkatkan karakteristik fisikokimia dan kualitas organoleptik dari minuman sari umbi bit.
Penelitian ini bertujuan untuk menganalisis pengaruh penambahan serai dan temu mangga terhadap karakteristik fisikokimia dan menentukan tingkat kualitas penerimaan organoleptik minuman sari umbi bit.

\section{METODE PENELITIAN}

\section{Alat dan Bahan}

Alat yang digunakan dalam proses pembuatan sari umbi adalah blender (Philips), timbang analitik (Mettler PJ 3000), termometer, pisau, panci, talenan, saringan, sendok, gelas ukur $100 \mathrm{~mL}$ (Pyrex), beaker glass $250 \mathrm{~mL}$ (Pyrex), dan beaker glass $1000 \mathrm{~mL}$ (pyrex). Alat yang digunakan dalam analisis fisikokimia adalah spektrofotometer (Shimadzu UVVis Mini 1240), pH meter (Hi 9812-5), hand refractometer (Atago N1).

Bahan baku yang digunakan adalah umbi bit varietas ayumi 04 berumur 45 hari setelah tanam yang diperoleh dari Desa Sumberejo, Kecamatan Ngablak, Kabupaten Magelang. Selain itu, bahan lain yang digunakan adalah serbuk serai merk "Supa", bubuk temu manga merk "Supa", madu merk "Melita" yang diproduksi oleh CV. Serangga Emas Apieres, air mineral. Bahan yang digunakan dalam analisis kimia antara lain larutan amilum $1 \%$, iodium (I2) $0,1 \mathrm{~N}$, larutan $\mathrm{pH}$ buffer 1 dan $\mathrm{pH}$ buffer 4,5 serta akuades.

\section{Tahapan Penelitian}

\section{Pembuatan Minuman Sari Umbi Bit}

Tahapan penelitian meliputi sortasi umbi bit, pencucian dengan air bersih, dilakukan pengupasan kulit, pemotongan umbi bit, blanching dengan suhu $60^{\circ} \mathrm{C}$ selama 3 menit. Penghancuran umbi bit dengan menggunakan blender, dilakukan penambahan air mineral dengan perbandingan antara bit dan air 1:2. Setelah itu, serbuk serai dan bubuk temu mangga ditambahkan secara terpisah ke dalam sari umbi dengan konsentrasi masing-masing $1 \%, 3 \%$, dan $5 \%$. Selanjutnya, sari umbi bit 
disaring, lalu ditambahkan madu 7\% dan dicampur hingga merata. Campuran ini kemudian disebut sebagai minuman sari umbi bit. Sebagai kontrol positif, sari umbi bit hanya ditambah 7\% madu, sedangkan kontrol negatif adalah sari umbi bit murni. Kemudian sari umbi bit disimpan dalam botol yang sudah bersih. Selanjutnya dilakukan pengukuran dan analisis total padatan terlarut, $\mathrm{pH}$ meter, vitamin $\mathrm{C}$, analisis kandungan betasianin, serta uji organoleptik

\section{Rancangan Percobaan}

Penelitian ini menggunakan rancangan acak kelompok (RAK) yang terdiri dari 1 faktor, yaitu perbedaan penambahan serai dan temu manga dengan masing-masing konsentrasi yang sama yaitu $1 \%, 3 \%, 5 \%$ pada minuman sari umbi bit, serta sebagai kontrol, sari umbi bit murni (kontrol negatif) dan sari umbi bit ditambah madu (kontrol positif). Data yang diperoleh kemudian dianalisis dengan analisis sidik ragam (ANOVA) untuk mengetahui pengaruh antar perlakuan. Apabila hasil yang diperoleh signifikan, maka dilanjutkan dengan uji DMRT (Duncan's Multiple Range Test) dengan tingkat kepercayaan $95 \%$.

\section{Metode Analisis}

Total Padatan Terlarut ( ${ }^{\circ}$ Brix) (Muchtadi dan Sugiyono, 1992)

Total padatan terlarut diukur dengan menggunakan Hand Refraktometer. Lensa Hand refraktometer dibersihkan dengan tissue yang telah diberi alkohol, lalu dikeringkan. Sebanyak 2-3 tetes sampel (minuman sari umbi bit) diletakkan pada lensa refraktometer. Diamati pada tempat yang cukup cahaya, kemudian dibaca total padatan terlarut sesuai skala pengukuran dan nilainya dinyatakan dalam ${ }^{\circ}$ Brix.

\section{pH Meter (Azizah dan Al-Baarri, 2012)}

Kalibrasi $\mathrm{pH}$ meter dilakukan dengan larutan buffer $\mathrm{pH} 4$ dan $\mathrm{pH} 7$. kemudian elektroda pada $\mathrm{pH}$ meter dibilas dengan akuades setiap mengganti buffer dan dikeringkan dengan tissue. Sebanyak $30 \mathrm{ml}$ larutan sampel $(1: 10 \mathrm{~b} / \mathrm{v})$ disiapkan dan dimasukkan ke dalam beakers glass. Elektroda $\mathrm{pH}$ metter dicelupkan pada sampel dan set pengukuran $\mathrm{pH}$. Elektrosa dibiarkan tercelup beberapa saat sampai diperoleh pembacaan yang stabil. Hasil pengukuran $\mathrm{pH}$ sampel dicatat dan setiap mengganti sampel elektroda dibilas dengan akuades dan dikeringkan dengan tisu.

\section{Analisis Vitamin C (AOAC, 1999)}

Analisis kandungan vitamin $\mathrm{C}$ menggunakan metode titrasi iodometri. Sebanyak $10 \mathrm{ml}$ larutan sampel (minuman sariumbi bit) dimasukkan ke dalam labu takar lalu ditambahkan aquades sampai batas tera. Larutan dikocok sampai merata. Selanjutnya sampel diambil $10 \mathrm{ml}$, dimasukkan ke dalam erlenmeyer, lalu ditambahkan aquades $20 \mathrm{ml}$ dan $2 \mathrm{ml}$ amilum dan dikocok sebentar lalu dititrasi dengan larutan iodium sampai larutan berwarna biru. Volume titrasi kemudian dicatat. Volume dihitung dengan rumus :

Vitamin $\mathrm{C}=$ volume titrasi $\mathrm{x} 0,88 \mathrm{mg}$ asamaskorbat $/ 10 \mathrm{ml}$ sari umbi bit

\section{Analisis Betasianin (Lestari, 2016)}

Mengencerkan zat warna yang terlalu pekat dengan memasukan $0,5 \mathrm{ml}$ zat warna dan ditambah 4,5 ml larutan buffer $\mathrm{pH} 1$ dan buffer $\mathrm{pH}$ 4,5 pada tabung reaksi, mengukur absorbansi sampel dengan panjang gelombang $537 \mathrm{~nm}$ dan $500 \mathrm{~nm}$, menghitung nilai kadar betasianin dengan rumus:

$\Delta$ Absorbansi $=[(\mathrm{A} 537-\mathrm{A} 500) \mathrm{pH} 1-(\mathrm{A} 537-$ A500) $\mathrm{pH} 4,5]$

$$
=\frac{\begin{array}{c}
\text { Kadar betasianin }(\mathrm{mg} / \mathrm{L}) \\
\text { Absorbansi } x \text { FP } x B M \times 1000
\end{array}}{(\Sigma \times \mathrm{l})}
$$

Keterangan :

$\Delta$ Absorbansi $=$ Selisih absorbansi pada $\mathrm{pH} 1$ dan pada $\mathrm{pH} 4,5$

Berat Molekul $=550 \mathrm{~g} / \mathrm{mol}$ $\sum=$ Koefisien absorbansi $=60.0001 / \mathrm{mol}$ $1=$ Tebal kuvet $1 \mathrm{~cm}$ 


\section{Uji Organoleptik (Setyaningsih et al., 2010)}

Tingkat kesukaan panelis terhadap produk minuman sari umbi bit diuji secara organoleptik dengan skala hedonik meliputi atribut warna, aroma dan rasa dengan 30 panelis tidak terlatih. Panelis menilai tiap sampel menurut tingkat kesukaan dengan skala penilaian yaitu 1 (sangat tidak suka), 2 (tidak suka), 3 (agak suka), 4 (suka), 5 (sangat suka). Dihadapan panelis ada 8 sampel produk yang dituangkan pada cup $50 \mathrm{~mL}$. Panelis minum air putih terlebih dahulu, kemudian panelis memcicipi satu persatu sari umbi bit dan memberikan penilaian sesuai dengan skala penilaian.

\section{HASIL DAN PEMBAHASAN}

Karakteristik fisikokimia yaitu total padatan terlarut, $\mathrm{pH}$ dan kadar vitamin $\mathrm{C}$ minuman sari umbi bit dengan penambahan serai dan temu mangga menghasilkan sifat yang berbeda-beda. Hal tersebut disajikan dalam Tabel 1

\section{Total Padatan Terlarut Sari Umbi Bit}

Total padatan terlarut dinyatakan dalam ${ }^{\circ}$ Brix. Total padatan terlarut pada minuman sari umbi bit menunjukkan bahwa perlakuan penambahan serai dan temu mangga dengan konsentrasi masing-masing tidak berbeda nyata, tetapi berbeda nyata dengan kontrol negatif (Tabel 1). Total padatan terlarut minuman sari umbi bit berada pada kisaran 0-6,9 ${ }^{\circ}$ Brix. Kontrol positif (sari umbi bit yang ditambah madu) meningkatkan total padatan terlarut, juga dilihat dari penambahan serai dan temu mangga maka menaikkan total padat terlarut. Tingginya total padatan terlarut ini disebabkan banyaknya padatan yang ditambahkan pada proses pembuatan produk (Susanto, 2011). Ismawati (2016), melaporkan bahwa total padatan terlarut sari bit sebesar $6^{\circ}$ Brix menunjukkan isi padatan terlarut adalah gula dan asam organik. Dalam penelitian ini, peningkatan total padatan terlarut pada minuman sari umbi bit dapat terjadi setelah ditambahkan madu, serai, dan temu mangga.

\section{Nilai pH Minuman Sari Umbi Bit}

Nilai pH merupakan salah satu parameter yang penting untuk diukur karena berhubungan dengan kualitas suatu produk pangan. Penambahan serai dan temu mangga dengan konsentrasi masingmasing $1 \%$, 3\%, dan 5\% memberikan pengaruh berbeda nyata dengan kontrol negatif (Tabel 1). Minuman sari umbi bit dengan kontrol positif, penambahan serai $1 \%$ dan temu mangga $1 \%, 3 \%$, dan $5 \%$ menunjukkan pengaruh berbeda nyata dengan minuman sari umbi bit yang ditambahkan dengan serai $3 \%$ dan $5 \%$. Nilai $\mathrm{pH}$ tertinggi adalah minuman sari

Tabel 1. Sifat fisikokimia minuman sari umbi bit dengan penambahan serai dan temu mangga

\begin{tabular}{lcccc}
\hline $\begin{array}{c}\text { Variasi minuman sari } \\
\text { umbi bit }\end{array}$ & $\begin{array}{c}\text { Total padatan } \\
\text { terlarut }\left({ }^{\circ} \text { Brix }\right)\end{array}$ & $\mathrm{pH}$ & $\begin{array}{c}\text { Vitamin C } \\
(\mathrm{mg} / 100 \mathrm{~g})\end{array}$ & $\begin{array}{c}\text { Betasianin } \\
(\mathrm{mg} / \mathrm{L})\end{array}$ \\
\hline Kontrol (-) & $0,00 \mathrm{~b}$ & $6,52 \mathrm{a}$ & $5,72 \mathrm{ab}$ & $7.74 \mathrm{bc}$ \\
Kontrol (+) & $6,40 \mathrm{a}$ & $6,00 \mathrm{~b}$ & $5,06 \mathrm{~b}$ & $2.77 \mathrm{e}$ \\
SR 1\% & $6,75 \mathrm{a}$ & $6,02 \mathrm{~b}$ & $6,16 \mathrm{a}$ & $4.51 \mathrm{~d}$ \\
SR 3\% & $6,30 \mathrm{a}$ & $5,82 \mathrm{c}$ & $5,28 \mathrm{ab}$ & $4.88 \mathrm{~d}$ \\
SR 5\% & $6,65 \mathrm{a}$ & $5,80 \mathrm{c}$ & $4,84 \mathrm{~b}$ & $6.83 \mathrm{~d}$ \\
TM 1\% & $6,75 \mathrm{a}$ & $6,02 \mathrm{~b}$ & $5,28 \mathrm{ab}$ & $7.74 \mathrm{bc}$ \\
TM 3\% & $6,45 \mathrm{a}$ & $6,00 \mathrm{~b}$ & $5,06 \mathrm{~b}$ & $8.09 \mathrm{~b}$ \\
TM 5\% & $6.92 \mathrm{a}$ & $6,02 \mathrm{~b}$ & $5,72 \mathrm{ab}$ & $10.26 \mathrm{a}$ \\
\hline
\end{tabular}

Keterangan: kontrol (-): sari umbi bit murni, kontrol (+): sari umbi bit+madu, SR: serai, TM: temu mangga *) angka yang diikuti huruf yang sama menunjukkan perbedaan yang tidak nyata pada uji Duncan 
umbi bit kontrol negatif (nilai 6,52) dan nilai $\mathrm{pH}$ terendah pada penambahan serai $5 \%$ (nilai 5,80). Tabel 1 menunjukkan bahwa kontrol positif (minuman sari umbi bit ditambah madu) menurunkan $\mathrm{pH}$, juga dilihat dari penambahan serai semakin tinggi konsentrasi, semakin turun nilai $\mathrm{pH}$. Namun disisi lain, penambahan temu mangga dengan masing-masing konsentrasi memiliki nilai $\mathrm{pH}$ yang stabil. Hal ini artinya dengan penambahan bahan tersebut maka minuman sari umbi bit memiliki tingkat $\mathrm{pH}$ yang rendah dibandingkan dengan kontrol negatif (sari umbi bit murni). Penurunan $\mathrm{pH}$ diduga adanya pemanis madu memiliki sifat asam yang dikontribusi oleh sejumlah kandungan asam organik (Oka et al., 2010), serta diduga adanya interaksi asam organik dari serai, sehingga menghalangi ionisasi karena terbentuknya agregat terlarut maupun tidak terlarut. (Lihninger, 1982) menyatakan bahwa semakin banyak jumlah asam yang ditambahkan pada larutan, semakin besar pula ion $\mathrm{H}+$ yang dilepaskan, sehingga menurunkan $\mathrm{pH}$. Pada penelitian ini $\mathrm{pH}$ minuman sari umbi bit berkisar 5,8-6,5. Nilai $\mathrm{pH}$ ini juga berkaitan dengan stabilitas pigmen yang terdapat dalam bit merah, khususnya betalain. Nilai $\mathrm{pH}$ untuk betalain berkisar antara pH 4-6 (Stintzing dan Carle, 2007).

\section{Vitamin C Minuman Sari Umbi Bit}

Bit merupakan sumber vitamin $\mathrm{C}$ yang kandungannya sebesar 4,90 mg/100g (USDA, 2014). Tabel 1 menunjukkan bahwa minuman sari umbi bit dengan penambahan serai dan temu mangga dengan konsentrasi masing-masing $1 \%$, $3 \%$, dan $5 \%$ memberikan pengaruh yang beda nyata. Sari umbi yang ditambahkan dengan serai $3 \%$ memberikan pengaruh tidak berbeda nyata dibandingkan dengan sari umbi yang ditambahkan temu mangga $1 \%, 5 \%$, serta pada kontrol negatif. Adapun sari umbi bit pada kontrol positif dibandingkan dengan yang ditambahkan serai 5\%, dan temu mangga $3 \%$ memberikan pengaruh tidak beda nyata (Tabel 1). Kadar vitamin C tertinggi terdapat pada minuman dengan penambahan serai $5 \%(6,16 \mathrm{mg} / 100 \mathrm{~g})$ dan terendah pada kontrol positif $(5,06$ $\mathrm{mg} / 100 \mathrm{~g}$ ).

Vitamin C dalam minuman sari umbi bit yang ditambahkan dengan serai dan temu mangga memberikan pengaruh yang berbeda nyata. Kandungan vitamin $\mathrm{C}$ pada minuman sari umbi bit dengan penambahan serai mengalami penurunan, diduga turunnya vitamin $\mathrm{C}$ karena proses pengolahan blanching, sehingga menurunkan kandungan vitamin $\mathrm{C}$. Vitamin $\mathrm{C}$ mudah terdegradasi selama pemanasan dalam waktu yang lama dan suhu tinggi (Lee et al., 2018), karena pada pemanasan molekul penyusun ikatan vitamin $C$ terputus sehingga dapat menyebabkan vitamin $\mathrm{C}$ terurai atau rusak (Hok et al, 2007). Hensall (1981) juga menyatakan bahwa kerusakan asam askorbat lebih banyak diakibatkan oleh pemanasan, karena okasidasi oksigen terjadi terhadap asam askorbat. Semakin besar nilai konsentrasi yang diberikan, maka nilai vitamin $\mathrm{C}$ di dalam minuman sari umbi bit akan semakin menurun. Hal ini diduga karena vitamin $\mathrm{C}$ merupakan vitamin yang tidak stabil dan mudah rusak selama pemanasan atau penyimpanan (de Mann, 1997).

\section{Betasianin Minuman Sari Umbi Bit}

Betasianin adalah salah satu pigmen yang berfungsi memberikan warna merah dan berpotensi sebagai pewarna alami untuk bahan pangan (Setiawan et al., 2015). Selain itu, betasianin merupakan jenis senyawa antioksidan yang kandungannya paling tinggi dalam umbi bit (WoottonBeard et al., 2011). Pengukuran betasianin dalam sari umbi bit bertujuan untuk mengukur perubahan kadar betasianin yang terkandung dalam sari umbi bit yang ditambahkan dengan bahan pangan.

Tabel 1 menunjukkan bahwa semua perlakuan memberikan pengaruh berbeda 
nyata terhadap minuman sari umbi bit. Betasianin pada kontrol negatif sebesar 7,43 $\mathrm{mg} / \mathrm{L}$ dibandingkan dengan kontrol positif yang kadar betasianin turun hingga 2,77 mg/L. Menurut Lestario et al., (2013) sari umbi bit memiliki kandungan betalain $(80,2 \mathrm{mg} / 100 \mathrm{~g}$ bb atau setara dengan 80,2 $\mathrm{mg} / 100 \mathrm{~mL})$. Menurut Ravichandran et al. (2013), kandungan betasianin akan berkurang seiring dengan adanya proses pengolahan dan degradasi. Beberapa faktor-faktor yang mempengaruhi betasianin bisa mengalami degradasi yaitu suhu, oksigen, cahaya, kadar gula dan enzim (Neelwarne, 2013). Demikian juga, penambahan serai diduga dapat menyebabkan penurunan dan kerusakan betasianin. Oleh karena itu, berdasarkan Tabel 1, perlu dilakukan penelitian lanjutan terkait dengan interaksi bahan pangan antara serai dengan betasianin yang terkandung dalam bit dan saat proses pembuatan minuman sari umbi bit.

Penambahan temu mangga 5\% menaikkan kandungan betasianin hingga 10,26 $\mathrm{mg} / \mathrm{L}$. Pada penambahan temu mangga, semakin tinggi konsentrasi yang diberikan maka menaikkan kandungan betasianin. Umbi bit memiliki komponen utama yaitu betasianin yang memberi pigmen dalam minuman sari umbi bit. Oleh karena itu kemungkinan dengan pencampuran temu mangga tidak terjadi penambahan betasianin melainkan terjadinya agregasi pada sari umbi bit dimana partikel-partikel kecil terbentuk dan terhitung pada saat menggunakan spektrofotometer.

Stabilitas betasianin dipengaruhi beberapa faktor yaitu $\mathrm{pH}$ dan suhu. Castellar et al. (2003), menyatakan bahwa betasianin memiliki kestabilan pada $\mathrm{pH} 5$ dan mengalami kerusakan di bawah $\mathrm{pH} 4$ (Ried et al., 1980). Coultate (1996) menambahkan bahwa nilai $\mathrm{pH}$ yang netral menyebabkan kerusakan betasianin dan berubah menjadi warna coklat. Selain itu, kondisi penyimpanan betasianin yang tidak vakum serta suhu yang tidak konstan juga dapat mempengaruhi kadar betasianin.

\section{Uji Organoleptik Minuman Sari Umbi Bit}

Pengujian organoleptik dilakukan menggunakan uji tingkat kesukaan yang dinyatakan dalam skala hedonik, sehingga diketahui kesukaan panelis terhadap minuman sari umbi bit. Adapun parameter yang diamati adalah warna, aroma dan rasa. Nilai tingkat kesukaan ditunjukkan pada Tabel 2.

Tabel 2. Nilai tingkat kesukaan terhadap minuman sari umbi bit dengan penambahan serai dan temu mangga

\begin{tabular}{lccc}
\hline $\begin{array}{l}\text { Variasi } \\
\text { minuman } \\
\text { sari umbi bit }\end{array}$ & Warna & Aroma & Rasa \\
\hline Kontrol (-) & $4,10 \mathrm{a}$ & $2,36 \mathrm{c}$ & $2,66 \mathrm{c}$ \\
Kontrol (+) & $3,86 \mathrm{~b}$ & $3,16 \mathrm{a}$ & $3,73 \mathrm{a}$ \\
SR 1\% & $3,86 \mathrm{~b}$ & $3,13 \mathrm{a}$ & $3,60 \mathrm{ab}$ \\
SR 3\% & $3,90 \mathrm{ab}$ & $3,13 \mathrm{a}$ & $3,33 \mathrm{ab}$ \\
SR 5\% & $3,86 \mathrm{~b}$ & $3,23 \mathrm{a}$ & $3,36 \mathrm{ab}$ \\
TM 1\% & $3,83 \mathrm{~b}$ & $3,00 \mathrm{ab}$ & $2,16 \mathrm{~b}$ \\
TM 3\% & $3,86 \mathrm{~b}$ & $2,66 \mathrm{bc}$ & $2,36 \mathrm{~cd}$ \\
TM 5\% & $3,93 \mathrm{ab}$ & $2,80 \mathrm{ab}$ & $1,96 \mathrm{~d}$ \\
\hline
\end{tabular}

Keterangan: kontrol (-): sari umbi bit murni, kontrol (+): sari umbi bit+madu, SR: serai, TM: temu mangga

*) angka yang diikuti huruf yang sama menunjukkan perbedaan yang tidak nyata pada uji Duncan

\section{Warna Minuman Sari Umbi Bit}

Penilaian kualitas sensori produk bisa dilakukan dengan melihat warna dikarenakan banyak sifat dan mutu komoditas dapat dinilai dari warna (Setyaningsih et al., 2010). Kesan pertama yang diperoleh dari suatu produk adalah warna. Selain mudah dikenali, warna merupakan karakteristik yang dapat mempengaruhi respon penerimaan atau penolakan terhadap suatu produk oleh konsumen (Mikasari et al., 2015).

Nilai kesukaan terhadap atribut warna minuman sari umbi bit menunjukkan 
bahwa penambahan serai dan temu mangga dengan konsentrasi masing-masing $1 \%$, $3 \%$, dan $5 \%$ memberikan pengaruh yang tidak berbeda nyata dengan kontrol negatif (Tabel 2). Adapun minuman sari umbi bit yang ditambahkan dengan temu mangga 5\% menunjukan tidak berbeda nyata dengan minuman sari umbi bit yang ditambahkan serai 3\%. Minuman sari umbi bit yang tambahkan dengan serai $1 \%$ menunjukan tidak berbeda nyata dengan yang penambahan serai $5 \%$, kontrol positif, temu mangga $1 \%$ dan $3 \%$.

Tabel 2 menunjukkan bahwa nilai kesukaan panelis terhadap warna minuman sari umbi bit yang paling tinggi yaitu kontrol negatif (nilai 4,10) dan nilai paling rendah yaitu temu mangga $1 \%$ (nilai 3,83). Secara keseluruhan sebenarnya warna sampel tidak terlalu menunjukan perbedaan nyata, artinya minuman sari umbi bit masih mempertahankan pigmen betasianin yang berwarna merah keunguan. Pigmen betasianin ini yang paling berperan dalam menentukan warna sari umbi (Chasparinda et al., 2014)

\section{Aroma Minuman Sari Umbi Bit}

Bau atau aroma merupakan sifat yang sulit untuk diklasifikasikan dan dijelaskan karena ragamnya yang begitu besar (Setyaningsih et al., 2010). Penilaian aroma suatu produk tidak terlepas dari indra penciuman. Menurut Winarno (1997) aroma atau bau yang diterima oleh hidung dan otak umumnya merupakan campuran empat bau utama, yaitu harum, asam, tengik, dan hangus. Minuman sari umbi bit memiliki aroma khas seperti tanah atau earthy taste yang kurang disukai oleh masyarakat. Oleh karena itu, dengan penambahan serai dan temu mangga sebagai flavor diharapkan dapat meminimalisir aroma tanah dari umbi bit.

Tabel 2 menunjukkan uji organoleptik terhadap aroma minuman sari umbi bit bahwa penambahan serai dan temu mangga dengan konsentrasi masing-masing $1 \%$, $3 \%$, dan $5 \%$ memberikan pengaruh yang berbeda nyata dengan kontrol negatif. Sari umbi bit kontrol positif menunjukkan pengaruh yang tidak berbeda nyata dibandingkan dengan penambahan serai $1 \%$, 3\%, dan 5\%. Adapun sari umbi bit yang ditambahkan temu mangga $1 \%$ dan $5 \%$ menunjukkan pengaruh yang tidak berbeda nyata, tetapi berbeda nyata dengan penambahan temu mangga 3\%. Adapun penilaian panelis terhadap kesukaan aroma minuman sari umbi bit paling tinggi yaitu dengan penambahan serai 5\% (nilai 3,23) karena perlakuan tersebut mampu meminimalisir aroma tanah (earthy taste) yang ada pada minuman sari umbi bit. Hal ini juga disebabkan karena serai memiliki senyawa citral yang membentuk aroma khas seperti lemon sehingga memiliki sifat penting dalam industri makanan dan penyedap rasa (Ariyani et al., 2008). Selain senyawa citral, serai juga memiliki kandungan utama seperti sitronelal, sitronelol, dan geraniol yang membuat serai memiliki aroma khas lemon (Ariyani et al., 2008). Penambahan berbagai variasi temu mangga pada minuman sari umbi bit menunjukan tidak beda nyata (Tabel 2). Namun, dengan aroma yang khas dan kuat mampu meminimalisir aroma tanah pada sari umbi bit. Komponen utama minyak atsiri dalam temu mangga seperti myrcene, $\beta$-pinene, $\beta$-Osimene (Dosoky \& Setzer, 2018) dan senyawa yang berperan memberikan aroma khas adalah $\delta$-3-karen dan (Z)- $\beta$ - (Hermani \& Suhirman, 2001).

Tingkat kesukaan panelis terhadap aroma paling rendah ditunjukkan pada kontrol negatif (nilai 2,36) karena yang dihasilkan aroma khas umbi bit seperti tanah (earthy taste). Aroma tanah disebabkan oleh adanya senyawa geosmin yang terdapat dalam umbi bit (Lu et al., 2003). Sesuai dengan (Ismawati, 2016), menyatakan aroma tanah yang dihasilkan oleh geosmin dapat menurunkan tingkat kesukaan seseorang terhadap produk. 


\section{Rasa Minuman Sari Umbi Bit}

Rasa merupakan salah satu faktor penentu dalam tingkat penerimaan panelis terhadap suatu produk. Menurut Winarno (1997), rasa dipengaruhi beberapa faktor antara lain senyawa kimia, konsentrasi, suhu, dan interaksi dengan komponen rasa lainnya. Nilai kesukaan rasa panelis pada minuman sari umbi bit menunjukkan semua perlakuan, baik kontrol negatif, kontrol positif, penambahan dengan perlakuan serai maupun penambahan temu mangga berbeda nyata antara perlakuan satu dengan yang lainnya (Tabel 2). Dari nilai kesukaan panelis terhadap rasa menunjukkan bahwa perlakuan kontrol positif memiliki nilai tertinggi di antara semua perlakuan yaitu nilai 3,73 , sedangkan pada perlakuan $5 \%$ temu mangga memiliki nilai terendah dari semua perlakuan yaitu 1,96. Pada perlakuan penambahan serai $1 \%, 3 \%$ dan $5 \%$ tidak menunjukan beda nyata tetapi berbeda nyata dengan penambahan temu mangga $1 \%, 3 \%$, dan 5\%. Adapun penambahan temu mangga $1 \%$ berbeda nyata dengan penambahan temu mangga $3 \%$ dan 5\%. Dari penilaian panelis terhadap rasa minuman sari umbi bit paling tinggi ditunjukkan pada kontrol positif karena sari umbi bit yang ditambahkan dengan madu menghasilkan rasa yang manis sehingga tidak hambar. Selain itu, madu yang ditambahkan pada sari umbi bit akan meminimalisir bau tanah yang terdapat dalam umbi bit. Rasa yang tidak bisa diterima oleh panelis ditunjukkan pada penambahan temu mangga 5\% karena rasa yang dihasilkan agak pahit dan rasa pekat seperti jamu, sehingga kurang disukai oleh panelis. Semakin tinggi konsentrasi temu mangga yang diberikan, maka penerimaan tingkat kesukaan panelis makin turun. Hal ini sesuai dengan (Abyan, 2018) yang menyatakan bahwa semakin tinggi konsentrasi temu mangga yang ditambahkan, maka akan kurang disukai karena memberikan rasa yang sepat pada minuman fungsional temu mangga.

\section{KESIMPULAN}

Penambahan serai dan temu mangga pada sari umbi bit meningkatkan total padatan terlarut, mempengaruhi kandungan betasianin, dan perubahan $\mathrm{pH}$. Total padatan terlarut tertinggi sebesar $6,92^{\circ} \mathrm{Brix}$ dan kandungan betasianin tertinggi sebesar $11,6 \mathrm{mg} / \mathrm{L}$ terjadi pada penambahan temu mangga 5\%. Nilai $\mathrm{pH}$ tertinggi ditunjukkan pada kontrol negatif (sari umbi bit murni) yaitu 6,52. Kandungan vitamin $\mathrm{C}$ tertinggi terdapat pada penambahan serai $1 \%$ yaitu $6,16 \mathrm{mg} / 100 \mathrm{~g}$.

Nilai kesukaan (organoleptik) oleh panelis dari segi warna, serai dan temu mangga yang ditambahkan pada sari umbi tidak memberikan pengaruh terhadap tingkat kesukaan panelis. Pada penilaian aroma menunjukkan bahwa penambahan serai dan temu mangga berpengaruh terhadap sari umbi bit. Aroma yang paling disukai oleh panelis yaitu dengan penambahan serai 5\% dengan nilai 3,23. Penilaian terhadap rasa menunjukkan bahwa penambahan bahan pangan berpengaruh terhadap sari umbi, tetapi kontrol positif (sari umbi bit dengan penambahan madu) menunjukkan yang paling dapat diterima oleh panelis (nilai $2,73)$.

\section{UCAPAN TERIMA KASIH}

Ucapan terima kasih kepada pihak Desa Sumberejo Kecamatan Ngablak, Kabupaten Magelang yang telah menyediakan umbi bit yang digunakan dalam penelitian ini.

\section{DAFTAR PUSTAKA}

Abyan, R. 2018. "Formulasi Potensi Minuman Fungsional Mengandung Antioksidan dari Temu Mangga (Curcuma mangga)". Skripsi. Ilmu dan Teknologi Pangan, Institut Pertanian Bogor, Bogor.

Agusta, A. 2002. Minyak Atsiri Tumbuhan Tropika Indonesia. Institut Teknologi Bandung, Bandung. 
AOAC. 1999. Official Methods of Analysis of the Association Analytical Chemistry. Washington, D.C.

Ariviani, S., dan Yani, F. 2013. Potensi temu mangga (Curcuma mangga $\mathrm{Val}$.) sebagai minuman fungsional. Jurnal Teknosains Pangan, 2 (3): 27-33.

Ariyani, F., Setiawan, L.E., dan Soetaredjo, F.E. 2008. Ekstraksi minyak atsiri dari tanaman serai dengan menggunakan pelarut metanol, aseton, dan N-heksan. Jurnal Widya Teknik, 2 (2): 124-133.

Azizah, N., Al-Baarri, A.N., Mulyani, S. 2012. Pengaruh lama fermentasi terhadap kadar alkohol, pH dan produksi gas proses fermentasi bioetanol dari whey dengan subtitusi kulit nanas. Jurnal Aplikasi Teknologi Pangan, 1 (2): 27-72.

BSN. 1995. SNI 01-3719-1995 tentang Minuman Sari Buah. Badan Standardisasi Nasional.

Castellar, R., Obón, J.M., Alacid, M., and Fernández-López, J.A. 2003. Color properties and stability of betacyanins from opuntia fruits. Journal of Agricultural and Food Chemistry, 51 (9): 2772-2776.

Chasparinda, E.M., Andriani, M.M.A.K. 2014. Pengaruh penambahan jahe (Zingiber officinale. R) terhadap karakteristik fisikokimia dan organoleptik sari buah bit (Beta vulgaris L.). Jurnal Teknosains Pangan, 3 (2): 20-27.

Coultate, T.P. 1996. Food the Chemistry of its Components. (3rd ed.). The Royal Society and Chemistry Compony.

Deman, J.M. 1997. Kimia Makanan Edisi Kedua (Edisi Kedua). Institut Teknologi Bandung, Bandung.

Dosoky, N.S., and Setzer, W.N. 2018. Chemical composition and biological activities of essential oils of curcuma species. Nutrients, 18: 1-42.

Hensall, J. 1981. Ascorbic acid in fruit juice and beverages dalam J.N. Counsell \& D.H Hornig, vitamin C. Applied Science.
Hermani dan Suhirman, S. 2001. Diversifikasi hasil tanaman temu mangga (Curcuma mangga Val.) perkembangan teknologi TRO. Balai Penelitian Tanaman Rempah dan Obat, 12: 43-54.

Hok, K.T., Setyo, W., Irawati, W., Soetaredjo, F. 2007. Pengaruh suhu dan waktu pemanasan terhadap kandungan Vitamin A dan C pada Proses. Jurnal Widya Teknik, 6 (2): 111-120.

Ismawati, N. 2016. Nilai pH, total padatan terlarut, dan sifat sensoris yoghurt dengan penambahan ekstrak Bit (Beta Vulgaris L.). Jurnal Aplikasi Teknologi Pangan, 5 (3): 89-93.

Lee, S., Choi, Y., Jeong, H.S., Lee, J., and Sung, J. 2018. Effect of different cooking methods on the content of vitamins and true retention in selected vegetables. Food Science and Biotechnology, 27 (2): 333-342.

Lestari, T.P. 2016. Analisis karakteristik ekstrak betasianin kulit buah naga hylocereus polyrhizus dan Hylocereus undatus serta uji stabilitas organoleptik jelly sebagai media pembelajaran atlas. Jurnal Pendidikan Biologi Indonesia, 2 (1): 78-87.

Lestario, L.N., Gunawan, N., Martono, Y. 2013. Pengaruh cahaya terhadap degradasi warna agar-agar yang diwarnai sari umbi bit merah (Beta vulgaris L. var.rubra.L). Agric, 25 (1): 42-50

Lihninger, A.L. 1982. Principles of Biochemistry. Worth Publishe.

Lu, G., Edwards, C.G., Fellman, J.K., Scott Mattinson, D., and Navazio, J. 2003. Biosynthetic origin of geosmin in red beets (Beta vulgaris L.). Journal of Agricultural and Food Chemistry, 51: 1062-1029.

Mastuti, R. 2010. Identifikasi pigmen betasianin pada beberapa jenis Inflorescence Celosia. Jurnal Biologi Universitas Gajah Mada, 10 (4): 667669. 
Mikasari, W., Hidayat, T., Ivanti, L. 2015. Mutu organoleptik dan nilai tambah sari buah jeruk rimau gerga lebong (Citratrus nobilis SP) berbulir dengan ekstraksi dan penambahan pewarna. Jurnal Agroindustri, 5 (2): 75-84.

Muchtadi, T. R. dan Sugiyono. 1992. Petunjuk Laboratorium Ilmu Pengetahuan Bahan Pangan. Dirjen Pendidikan Tinggi PAU Pangan dan Gizi.

Neelwarne, B., and Halagur, S.B. 2013, Red Beet Biotechnology: Food and Pharmaceutical Applications, Springer Science-Business Media, New York

Oka, A.P.I., Ratnayani, K., dan Listya, A. 2010. Aktivitas antiradikal bebas serta kadar beta karoten pada madu randu (Ceiba petandra) dan madu kelengkeng (Nephelium longata L.). Journal of Chemistry, 4 (1): 54-62.

Ravichandran, K., Saw, N.M.M.T., Mohdaly, A.A.A., Gabr, A.M.M.T., Kastell, A., Riedel, H., and Smetanska, I. 2013. Impact of processing of red beet on betalain content and antioxidant activity. Food Research International, 50 (2): 570-675.

Ried, M., Jack, S., Palu, P., and Young, R. E. 1980. Effects of $\mathrm{pH}$ and ethephon on betacyanin leakage from beet root disc. Journal Plant Physiol, 66: 1015-1016.

Riskesdas. 2010. Badan Penelitian dan Pengembangan Kementerian Kesehatan. Badan Penelitian dan Pengembangan Kesehatan. [https://doi.org/1 Desember 2013]. (Diakses tanggal 20 Desember 2019).

Sarjono, P.R., dan Mulyani, N.S. 2007. Aktivitas antibakteri rimpang temu putih (Curcuma mangga Vall ). Jurnal Sains \& Matematika (JSM), 15 (2): 89-93.

Setiawan, M.A.W., Nugroho, E.K., dan Lestario, L.N. 2016. Ektraksi betasianin dari kulit umbi bit (Beta vulgaris) sebagai pewarna alami. Jurnal Agric., 27 (1\&2): 38-43.

Setyaningsih, D., Apriyantono, A., Sari, M. 2010. Analisis Sensori. Institut Pertanian Bandung Press, Bandung.
Stintzing, F.C., dan Carle, R. 2007. Betalains emerging prospects for food scientists. Trends in Food Science and Technology, 18: 514-525.

Susanto, D. 2011. Potensi Bekatul Sebagai Sumber Antioksidan. Universitas Diponegoro, Semarang.

Székely, D., Furulyás, D., and Stéger-Máté, M. 2019. Investigation of mineral and vitamin $\mathrm{C}$ contents in different parts of beetroots (Beta vulgaris L.). Notulae Botanicae Horti Agrobotanici ClujNapoca, 47(3): 615-620.

USDA. 2014. Nutritional vuleu of Beet raw. http://ndb.nal.usda.gov.

[Diakses tanggal 20 November 2019].

Winarno, F. 1997. Kimia Pangan dan Gizi. Gramedia Pustaka Media, Jakarta.

Wootton-Beard, P.C., Moran, A., and Ryan, L. 2011. Stability of the total antioxidant capacity and total polyphenol content of 23 commercially available vegetable juices before and after in vitro digestion measured by FRAP, DPPH, ABTS and Folin-Ciocalteu methods. Food Research International, 44: 17-224. 